\title{
Improving Teaching and Learning of Glycolysis and Kerbs' Cycle using Concept Mapping Technique
}

\author{
Y. Ameyaw 1
}

${ }^{1}$ Department of Biology Education, Faculty of Science Education, University of Education, Winneba - C/R

\begin{abstract}
The purpose of this study is to investigate the use of concept map to enhance academic performance of students in Glycolysis and Krebs cycle. Sixty-three (63) second year students from Odorgonno Senior High School (OSSA) in the Greater Accra Region of Ghana were used for the study. A quasi-experimental design which combines both qualitative and quantitative with inclusion of participatory design was used to gather information from students' concept maps (interventional tool used) on Glycolysis and Krebs cycle. Closeness index technique designed by Goldsmith, Johnson and Acton (1991) was used to assess students' concept maps. The outcome of the study disclosed high performance of students' skills in concept map construction and a significant increase in students' understanding of Glycolysis and Krebs cycle; concepts in tissue respiration. The study portrayed a significant difference between the pre-test and post-test scores and this suggests that concept mapping is an effective tool that can enhance SHS students' academic performance in Glycolysis and Krebs cycle.
\end{abstract}

Keywords: Academic performance, Achievement levels, Senior High School (SHS), Concept mapping, Closeness index

\section{Introduction}

Glycolysis and Krebs cycle are two major concepts in cellular respiration. Students normally face difficulties in grasping the two concepts and the chemical processes involved (Songer \& Mintzes, 1994). Some SHS students are not clear about the principles and phenomenon governing the two concepts, and unable to distinguish between cellular respiration and photosynthesis, and again, even identify the site where cellular respiration takes place (Seymore \& Longden, 1991; Marmaroti \& Galanopoulou, 2006). These are the fundamentals or the pre-requisite knowledge needed to understand the two concepts; glycolysis and Krebs cycle. Therefore it is imperative to find the various ways necessary to assist learners to conceptualise and assimilate concepts perceived as difficult and un-understandable (Abimbola, 1987). Therefore cognitive scientists have being trying to find out how human beings store, retrieve and use knowledge, and how existing knowledge affects communication, learning and the performance in comprehension and problem solving (Abimbola, 1987). As a result, this study assesses the effectiveness of concept mapping which according to Ameyaw (2012), has become popular and effective as a twenty-first century teaching strategy to help students of SHS to enhance their understanding of glycolysis and Krebs cycle. Concept maps are graphical representations of knowledge comprising concepts and linkages/crosslinks between them. They are presented in a hierarchical fashion with the most inclusive, most general concepts at the top of the map followed by the more specific with the less general concepts arranged below. One important characteristic of concept maps is the inclusion of "crosslinks" that make explicit relationships among concepts in different regions or domains within the maps. Cross-links show how a concept in one domain of knowledge is related to a concept in another domain shown on the map. Concept map is an extension of David Ausubel's work on cognitive theory of learning. According to Ausubel (1978), learning takes place by the assimilation of new concepts and propositions into existing concept and propositional frameworks (cognitive structures) held by the learner. Interestingly, concept map seeks to promote student understanding in a concept rather than promoting rote learning as evidenced in Ausubel's meaningful learning (Ausubel, 1978). Ausubel projected meaningful learning to the disadvantage of rote learning by indicating that meaningful learning requires three conditions:

1. The material to be learned must be conceptually clear and presented in a

This article is published under the terms of the Creative Commons Attribution License 4.0

Author(s) retain the copyright of this article. Publication rights with Alkhaer Publications.

Published at: http://www.ijsciences.com/pub/issue/2015-06/

Article Number: V4201506706; Online ISSN: 2305-3925; Print ISSN: 2410-4477 
language and relatable to the learner's prior knowledge.

2. The learner must possess relevant prior knowledge, and

3. The learner must choose to learn meaningfully.

Concept maps are helpful in meeting the above conditions by identifying general concepts prior to instruction in more specific concepts. It assists in sequencing learning tasks through progressively more explicit knowledge that anchors developing conceptual frameworks by incorporating new meanings into prior knowledge.

Concept map fosters meaningful learning because it encourages students to use meaningful-mode learning patterns by helping student to identify both valid and invalid ideas held by them (Novak \& Gowin, 1984; Novak, 1998; Mintzes, Wandersee \& Novak, 2000). In a study by Horton, McConney, Gallo, Senn \& Hamelin, (1993), concept maps appear especially good in comparison to other interventions, for the learning of relationships among concepts. An explicit and unique feature of concept map is the existence of diverse alternative approaches to Concept Map construction. The diversities could be based on the use of software tools, the pre-specification of concepts of individuals versus collaborative mapping (Cañas et. al., 2003). According to Canas et. al.,( 2003), several facilitation procedures are available in concept map construction for novices learning to create concept maps as well as group of experts who work in conjunction with a facilitator or knowledge engineer. Apart from the diversities in facilitation procedures, concept maps have several applications such as; scaffolding, consolidation of exceptional experience, improvement of affective conditions for learning, an alternative to traditional writing assignments, a mediating representation for supporting interaction among learners, and aiding the process of learning by teaching. Concept maps have been useful in several ways such as organizing and presenting information, as an Advance Organizer, as a navigational aid in hypermedia and for curriculum design, and use (Canas et. al., (2003). Concept map is a systematic tool for theory of assimilation that depicts elementary elements such as subsumption, integrative reconciliation and progressive differentiation (Ausubel, Novak, \& Hanesian, 1978). It has been noticed that after over thirty years of Novak's proposal on the usefulness of concept map, researchers are still impressed by its versatility in curriculum design (Edmondson, 1995), teaching strategy (Schmid \& Telaro, 1990), and evaluation of teaching (Beyerbach \& Smith, 1990). A concept map is made up of conventional propositions consisting of concepts and their relations (nodes and links respectively) which serve as a guide in arousing user curiosity to link concepts. In spite of the usefulness of the concept maps, some researchers have reported that concept mapping techniques have some conspicuous disadvantages such as; inconveniencing the teacher to provide appropriate feedback to students when concept maps are used in teaching, its complex and difficult nature for students to design, especially novice, and difficult to evaluate (Chang, Sung, \& Chen, 2001). Although such weaknesses associated with concept maps as indicated by Chang, Sung, and Chen, (2001) has been documented, they failed to recognised that researchers have built computer-based concept mapping systems and software to help students construct concept maps without constraints (Chang, Sung, \& Chen, 2001). It is upon the above antagonistic views coupled with students' difficult understanding of glycolysis and Krebs cycle that this study is designed to unearthed concept mapping as a teaching and learning tool of the two (2) concepts: glycolysis and Krebs cycle using the hypotheses given below to address this research;

$\mathrm{H}_{1}$ : There is a significant difference between concept maps designed by students in the experimental group and that of the experts before the intervention techniques.

$\mathrm{H}_{2} \quad$ Concept mapping technique of teaching and learning has a significant effect on

students' achievement levels in glycolysis and Krebs cycle.

$\mathrm{H}_{3}$ : There is a significant difference between concept maps designed by students in

the experimental group before and after the intervention techniques.

\section{Methodology}

The design used a quasi-experimental design to determine the effectiveness of concept mapping in teaching glycolysis and Kreb cycle. Quasiexperiment is a type of research design which exposes research subjects to treatment conditions using nonrandomized designs (Keppel, 1991). The study also employed participatory design which according to Creswell (1994), is recursive or dialectical in nature to change in practices. Participatory study focuses on change, helping individuals to free themselves from constraints found in educational settings and empowers individuals exposed to it.

Participatory design is also known to be emancipatory, helps unshackle people from the constraints of irrational and unjust structures that limit self-development and self-determination (Creswell, 1994). It is therefore appropriate for this study. The sample population was drawn from students reading biology as elective course in the Odorgonno Senior High Schools in the Ga South Metropolis of the Greater Accra Region of Ghana through sample of convenience. The accessible population of twenty-nine (29) students comprising 
twelve (12) girls and seventeen (17) boys was randomly selected and used for the study. All the twenty-nine participants were subjected to preinterventional test to determine

whether the research subjects were of equal ability level before grouping them into three ability groups based upon their achievement scores. A score above seventy percent $(70 \%)$ was considered as High Achiever, a scored between fifty percent and seventy percent $(50 \%>\mathrm{x}<70 \%)$ was classified as Middle Achiever. However, a score below fifty percent (50\%) was considered as Low Achiever (Ameyaw, 2012). The three groups were further divided into three sub groups depending upon the strength of the score of a student comparative to those of the same achieving group. For instance, the High achievers group was divided into high, middle and low groups with the high group comprising of students who scored between $50 \%$ and $60 \%$. The middle group of the high achievers comprised of students who scored between $34 \%$ and $38 \%$ where as students in the high achievers group who scored between $30 \%$ and $26 \%$ were considered as low group as indicated in Table 8 . The research participants (individuals in the experimental group) were taken through concept map lessons on the same topics. Post-interventional assessment was administered to determine the effectiveness of concept mapping on the achievement levels of the nine sub groups in the experimental group. The pre-interventional scores and postinterventional scores of the experimental group were subjected to t-test to test the hypothesis three $\left(\mathrm{H}_{3}\right)$. In order to test the hypothesis three $\left(\mathrm{H}_{3}\right)$, the concept maps developed by students in the experimental group after the intervention were subjected to close

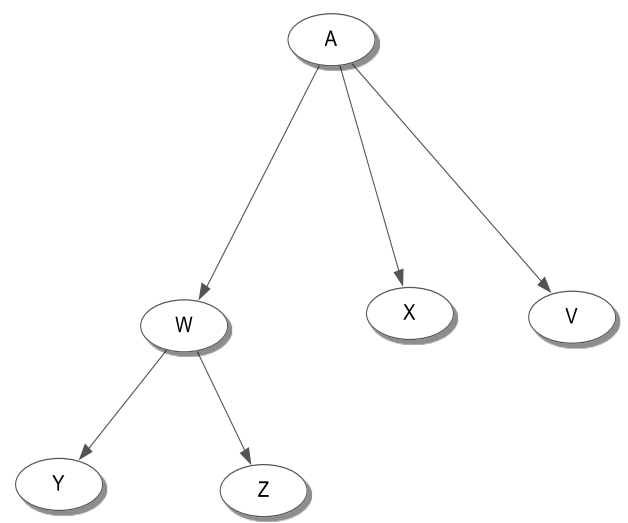

Fig. 1a: Model of Expert Concept Map (E)

For instance, in Figure 1a, node A has links to nodes $\mathrm{W}, \mathrm{X}$ and $\mathrm{V}$, in the expert's (teacher's) map $\left(\mathrm{G}_{\mathrm{E})}\right.$, but

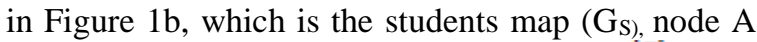
is connected to nodes $\mathrm{U}$ and $\mathrm{V}$. Therefore, $\mathrm{N}_{n}^{(E)}=\{\mathrm{U}$, $\mathrm{V}\}$ and $\mathrm{N} \underset{n}{(S)}=\{\mathrm{W}, \mathrm{X}, \mathrm{Y}\}$. Having determined the index (CI) analysis developed by Goldsmith, Johnson \& Acton (1991) explained as:

\section{Techniques for Closeness Index scoring}

The closeness index, devised by Goldsmith, Johnson and Action (1991), is an empirical technique that aims to calculate the similarity between a student's and a teacher's concept maps. The approach focuses on the concepts and links between concepts that are common in the two maps but it ignores the labels of the links. The closeness index (CI) of a concept (c) that the student's and teacher's maps have in common equals the number of concepts directly linked to (c) in both maps divided by the number of concepts directly linked to (c) in either map. The overall closeness index of two maps is then calculated as the average closeness index over all nodes in those maps. Thus, figure 1a and $\mathrm{b}$ (concept maps designed by teacher(expert) and students in the experimental groups were used to illustrate the comparative method proposed by Goldsmith et al. (1991). Figure 1(a) which is as an expert's concept map has the formula; $\mathrm{G}_{\mathrm{e}}=(\mathrm{Ve}, \mathrm{Ee})$, where $\mathrm{Ve}$ represents the sets of concept nodes and Ee represents relation links in the map. In Figure 1(b) is a model student concept map designed by the first group of the High achievers and has the formula Gs= (Vs, Es), where Vs and Es respectively represent concept nodes and concept links of students. The two maps can be compared by searching in each of them for concept nodes that are connected to each node $n$ from $V=V_{e} U_{V s}$ (that is the union of the two nodes). The sets of such nodes are represented as $\mathrm{N}_{n}^{(E)}$ and $\mathrm{N}_{n}^{(s)}$, where $\mathrm{N}$ is the number of linking nodes, $\mathrm{n}$ represents nodes and (E) and (s) also represent expert and student concept maps respectively.

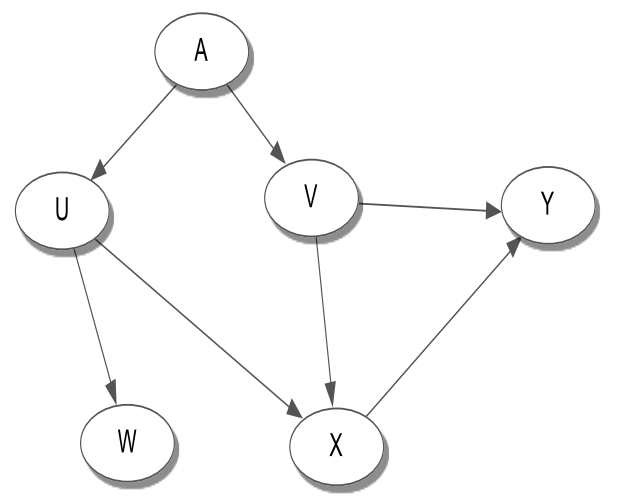

Fig. 1b: Model of Student Concept Map (S)

sets of adjacent nodes for a given concept maps, the intersection and the union of the set nodes in the given concept maps (in this case two sets) can be determined by $\left(\mathrm{In}=\mathrm{N}_{n}^{(E)} \cap N_{n}^{(S E)}\right)$ and their union $\left(\mathbf{U}_{n}=N_{n}^{(E)} \cup N_{n}^{(s)}\right)$ respectively. In this case, the 
intersection of Figure $1 \mathrm{a}$ and $1 \mathrm{~b}\left(\mathrm{I}_{\mathrm{n}}\right)$ will be $\{\square\}$, that is empty set, and their union $\mathrm{U}_{\mathrm{n}}$ will be $\{\mathrm{U}, \mathrm{V}, \mathrm{W}$, $\mathrm{X}\}$. The closeness index (CI) for nodes (n) can therefore be defined $n$ as $C I_{n}=\left|\frac{I_{n}}{U_{n}}\right|$, where || means the number of nodes in the set, $\mathrm{I}_{\mathrm{n}}$, intersection of the nodes and $\mathrm{U}_{\mathrm{n}}$, union of the nodes. By this definition the closeness Index for node ' $\mathrm{A}$ ' in figure $1 \mathrm{a}$ and $1 \mathrm{~b}$ can be calculated as $\mathrm{C}_{\mathrm{A}}=\left|\frac{\mathrm{I}_{\mathrm{A}}}{\mathrm{U}_{\mathrm{A}}}\right|=\frac{0}{4}=0$.

After the closeness indexes for all nodes in the two concept maps are calculated we can define the closeness index of the two concept maps as: $\mathrm{C}(\mathrm{Ge}, \mathrm{Gs})=\frac{1}{|V|} \sum_{\mathrm{iv}} C i$, where $V=V e \cup V s$.

Therefore the total closeness index is also zero (0)

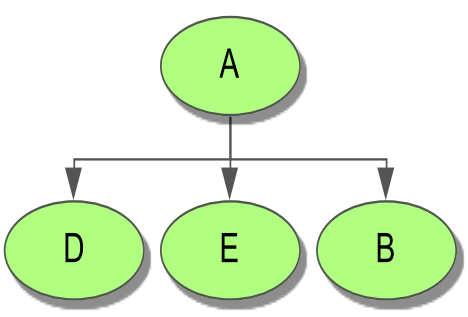

Fig. 2a: Expert Concept Map

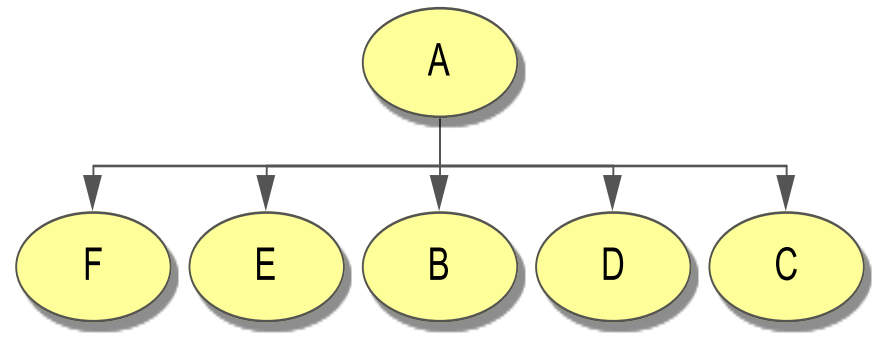

Fig. 2b: Student Concept Map

Upon a critical look at the total closeness index of 0 , it can be surmised that Figure $1 \mathrm{~b}$ is not constructed to standard. This is because the total closeness index of zero implies that no work was apparently done by the student in question. On the other hand, in Figures 2a and $2 b$, the total closeness index is 0.6 which is approaching one, an indication of a good job by the student after the intervention.

\section{Results}

The study adopted the closeness index scoring scheme designed by Goldsmith, et. al., (1991) and used it for scoring the nine concept maps designed by each sub-group in the experimental group. The scoring key for the nodes are presented in Table 1.

\section{TABLE 1: Comparison between expert's (teacher) node and student's concept map nodes}

$$
\begin{aligned}
& A=\text { Mitochondrion } \\
& B=\text { Outer Membrane } \\
& \text { C }=\text { Matrix } \\
& \text { D = Inner Membrane } \\
& \mathrm{E}=\text { Membrane gaps } \\
& \mathrm{F}=\text { Folds } \\
& \mathrm{G}=\text { Energy Flow } \\
& \mathrm{H}=\text { Cellular Respiration } \\
& \mathrm{I}=\text { Internal Respiration } \\
& \mathrm{J}=\text { Glycolysis } \\
& \mathrm{K}=\text { Pyruvic Acid } \\
& \mathrm{L}=\text { Glucose }
\end{aligned}
$$

$\mathrm{H}_{1}$ : There is a significant difference between concept maps designed by Students in the experimental group and that which was designed by experts before the Intervention techniques.

This hypothesis was tested by finding the closeness index of students' concept map that was designed before the intervention was administered. This was done by finding the CI score of the high achievers group that ranked first in the pre-interventional concept map designed test. There was only one group that was able to design something that resembled concept map (Figure 1b). However, the CI score for this concept map (Figure 1b) was zero. Therefore the hypothesis was not rejected. This means, there was a significant difference between the concept maps designed by students in the experimental group and the expert concept map at the pre-interventional stage.

\section{H2: Concept mapping technique of teaching and learning has no significant effect on Students' achievement in glycolysis and Krebs cycle}

This second hypothesis was tested by finding the closeness index of the Nine (9) concept maps designed by the Nine (9) Achieving groups in the post interventional concept map design test. Three of the CI scores and their average mean scores from one group of each of the Three Achievers' levels have been presented in Tables 2, 3, 4, 5, 6 and 7 for the purpose of the discussion. The average mean scores 
of each Achievers levels (The Three High Achievers, the Three Middle Achievers and the Three Low Achievers) presented in Tables 3, 5 and 7 shows averages of $0.96,0.95$ and 0.91 respectively. These figures are all approaching one (1); an indication of a good performance. Therefore the second hypothesis cannot be rejected and this means, concept mapping technique of teaching has significant effect on SHS students' achievement in glycolysis and Krebs cycle. The star sign $(*)$ in the tables was used to indicate particular points where students made mistakes by adding additional keys to the expected ones whereas the question mark (?) was used in places within the tables where students made omissions.

Table 2: Comparison between expert's (teacher's) node and nodes of First group of High Achievers concept map as sample for second and third groups

\begin{tabular}{|c|c|c|c|c|c|}
\hline $\mathrm{U}$ & $\mathrm{N}_{\mathrm{n}}^{(\mathrm{E})}$ & $\mathrm{N}_{\mathrm{n}}^{(\mathrm{s})}$ & $\mathrm{I}_{\mathrm{n}}$ & $\overline{U_{n}}$ & $\mathrm{C}_{\mathrm{n}}$ \\
\hline $\mathrm{A}=$ Mitochondrion & $\{\mathrm{C}, \mathrm{D}, \mathrm{E}\}$ & $\{\mathrm{C}, \mathrm{D}, \mathrm{E}\}$ & $\{\mathrm{C}, \mathrm{D}, \mathrm{E}\}$ & $\{\mathrm{C}, \mathrm{D}, \mathrm{E}\}$ & 1 \\
\hline $\mathrm{B}=$ Outer Membrane & $\{\mathrm{D}, \mathrm{C}\}$ & $\{\mathrm{D}, \mathrm{C}\}$ & $\{\mathrm{D}, \mathrm{C}\}$ & $\{\mathrm{D}, \mathrm{C}\}$ & 1 \\
\hline $\mathrm{C}=$ Matrix & $\{\mathrm{C}, \mathrm{A}, \mathrm{D}\}$ & $\begin{array}{l}\left\{\mathrm{C}, \mathrm{A}, \mathrm{D}, \mathrm{V}^{*}\right. \\
\}\end{array}$ & $\{\mathrm{C}, \mathrm{A}, \mathrm{D}\}$ & $\begin{array}{l}\left\{\mathrm{C}, \mathrm{A}, \mathrm{D}, \mathrm{V}^{*}\right. \\
\}\end{array}$ & 0.8 \\
\hline $\mathrm{D}=$ Inner Membrane & $\{\mathrm{M}, \mathrm{T}, \mathrm{N}\}$ & $\{\mathrm{M}, \mathrm{T}, \mathrm{N}\}$ & $\{\mathrm{M}, \mathrm{T}, \mathrm{N}\}$ & $\{\mathrm{M}, \mathrm{T}, \mathrm{N}\}$ & 1 \\
\hline $\mathrm{E}=$ Membrane gaps & $\{\mathrm{D}, \mathrm{E}\}$, & $\{\mathrm{D}, \mathrm{E}\}$, & $\{\mathrm{D}, \mathrm{E}\}$, & $\{\mathrm{D}, \mathrm{E}\}$, & 1 \\
\hline $\mathrm{F}=$ Folds & $\{\mathrm{A}, \mathrm{C}\}$ & $\{\mathrm{A}, \mathrm{C}\}$ & $\{\mathrm{A}, \mathrm{C}\}$ & $\{\mathrm{A}, \mathrm{C}\}$ & 1 \\
\hline $\mathrm{G}=$ Energy Flow & $\{\mathrm{B}, \mathrm{Y}, \mathrm{Q}\}$ & $\{\mathrm{B}, \mathrm{Y}, \mathrm{Q}\}$ & $\{\mathrm{B}, \mathrm{Y}, \mathrm{Q}\}$ & $\{\mathrm{B}, \mathrm{Y}, \mathrm{Q}\}$ & 1 \\
\hline $\mathrm{H}=$ Cellular Respiration & $\{\mathrm{J}, \mathrm{A}, \mathrm{V}\}$ & $\{\mathrm{J}, \mathrm{A}, \mathrm{V}\}$ & $\{\mathrm{J}, \mathrm{A}, \mathrm{V}\}$ & $\{\mathrm{J}, \mathrm{A}, \mathrm{V}\}$ & 1 \\
\hline $\mathrm{I}=$ Internal Respiration & $\{\mathrm{V}, \mathrm{J}, \mathrm{A}\}$ & $\{\mathrm{V}, \mathrm{J}, \mathrm{A}\}$ & $\{\mathrm{V}, \mathrm{J}, \mathrm{A}\}$ & $\{\mathrm{V}, \mathrm{J}, \mathrm{A}\}$ & 1 \\
\hline $\mathrm{J}=$ Glycolysis & $\{\mathrm{L}, \mathrm{J}\}$ & $\{\mathrm{L}, \mathrm{J}\}$ & $\{\mathrm{L}, \mathrm{J}\}$ & $\{\mathrm{L}, \mathrm{J}\}$ & 1 \\
\hline $\mathrm{K}=$ Pyruvic Acid & $\{\mathrm{Q}, \mathrm{J}\}$, & $\{\mathrm{Q}, \mathrm{J}\}$, & $\{\mathrm{Q}, \mathrm{J}\}$, & $\{\mathrm{Q}, \mathrm{J}\}$, & 1 \\
\hline $\mathrm{L}=$ Glucose & $\{\mathrm{XY}, \mathrm{Z}\}$ & $\{\mathrm{XY}, \mathrm{Z}\}$ & $\{\mathrm{XY}, \mathrm{Z}\}$ & $\{\mathrm{XY}, \mathrm{Z}\}$ & 1 \\
\hline $\mathrm{M}=$ Cytoplasm & $\{\mathrm{N}, \mathrm{Y}, \mathrm{K}\}$ & $\{\mathrm{N}, \mathrm{Y}, \mathrm{K}\}$ & $\{\mathrm{N}, \mathrm{Y}, \mathrm{K}\}$ & $\{\mathrm{N}, \mathrm{Y}, \mathrm{K}\}$ & 1 \\
\hline $\mathrm{N}=\mathrm{NADH}$ & $\{\mathrm{V}, \mathrm{O}\}$ & $\{\mathrm{V}, \mathrm{O}\}$ & $\{\mathrm{V}, \mathrm{O}\}$ & $\{\mathrm{V}, \mathrm{O}\}$ & 1 \\
\hline $\mathrm{O}=\mathrm{ATP}$ & $\{\mathrm{N}, \mathrm{K}\}$ & $\{\mathrm{N}, \mathrm{K}\}$ & $\{\mathrm{N}, \mathrm{K}\}$ & $\{\mathrm{N}, \mathrm{K}\}$ & 1 \\
\hline $\mathrm{P}=$ Krebs cycle & $\{\mathrm{N}, \mathrm{X}, \mathrm{Z}\}$ & $\{\mathrm{N}, \mathrm{X}, \mathrm{Z}\}$ & $\{\mathrm{N}, \mathrm{X}, \mathrm{Z}\}$ & $\{\mathrm{N}, \mathrm{X}, \mathrm{Z}\}$ & 1 \\
\hline $\mathrm{Q}=\mathrm{CO}_{2}$ & $\{\mathrm{~V}, \mathrm{~N}, \mathrm{~B}\}$ & $\{\mathrm{V}, \mathrm{N}, \mathrm{B}\}$ & $\{\mathrm{V}, \mathrm{N}, \mathrm{B}\}$ & $\{\mathrm{V}, \mathrm{N}, \mathrm{B}\}$ & 1 \\
\hline $\mathrm{R}=$ Electron Transport & $\{\mathrm{U}, \mathrm{Z}\}$ & $\{\mathrm{U}, \mathrm{Z}\}$ & $\{\mathrm{U}, \mathrm{Z}\}$ & $\{\mathrm{U}, \mathrm{Z}\}$ & 1 \\
\hline $\mathrm{S}=\mathrm{ADP}$ & $\{\mathrm{O}, \mathrm{R}, \mathrm{Y}\}$ & $\{\mathrm{O}, \mathrm{R}, \mathrm{Y}\}$ & $\{\mathrm{O}, \mathrm{R}, \mathrm{Y}\}$ & $\{\mathrm{O}, \mathrm{R}, \mathrm{Y}\}$ & 1 \\
\hline $\mathrm{T}=$ Energy Investment Phase & $\{\mathrm{X}, \mathrm{R}, \mathrm{Y}\}$ & $\{\mathrm{X}, \mathrm{R}, \mathrm{Y}\}$ & $\{\mathrm{X}, \mathrm{R}, \mathrm{Y}\}$ & $\{\mathrm{X}, \mathrm{R}, \mathrm{Y}\}$ & 1 \\
\hline $\mathrm{U}=$ Energy Harvest Phase & $\{\mathrm{Q}, \mathrm{N}, \mathrm{O}\}$ & $\{\mathrm{Q}, \mathrm{N}, \mathrm{O}\}$ & $\{\mathrm{Q}, \mathrm{N}, \mathrm{O}\}$ & $\{\mathrm{Q}, \mathrm{N}, \mathrm{O}\}$ & 1 \\
\hline $\mathrm{V}=$ Acetyl CoA & $\{\mathrm{Q}, \mathrm{O}, \mathrm{X}, \mathrm{N}\}$ & $\begin{array}{l}\{\mathrm{Q}, \mathrm{O}, \mathrm{X}, \mathrm{N} \\
\}\end{array}$ & $\begin{array}{l}\{\mathrm{Q}, \mathrm{O}, \mathrm{X}, \mathrm{N} \\
\}\end{array}$ & $\begin{array}{l}\{\mathrm{Q}, \mathrm{O}, \mathrm{X}, \mathrm{N} \\
\}\end{array}$ & 1 \\
\hline $\mathrm{W}=\mathrm{FAD}$ & $\{\mathrm{R}, \mathrm{N}, \mathrm{K}\}$ & $\{\mathrm{R}, \mathrm{N}, \mathrm{K}\}$ & $\{\mathrm{R}, \mathrm{N}, \mathrm{K}\}$ & $\{\mathrm{R}, \mathrm{N}, \mathrm{K}\}$ & 1 \\
\hline $\mathrm{X}=\mathrm{FADH}_{2}$ & $\{\mathrm{~A}, \mathrm{D}, \mathrm{C}\}$ & $\{\mathrm{A}, \mathrm{D}, \mathrm{C}\}$ & $\{\mathrm{A}, \mathrm{D}, \mathrm{C}\}$ & $\{\mathrm{A}, \mathrm{D}, \mathrm{C}\}$ & 1 \\
\hline $\mathrm{Y}=\mathrm{H}_{2} \mathrm{O}$ & $\{\mathrm{X}, \mathrm{R}, \mathrm{O}\}$ & $\{\mathrm{X}, \mathrm{R}, \mathrm{O}\}$ & $\{\mathrm{X}, \mathrm{R}, \mathrm{O}\}$ & $\{\mathrm{X}, \mathrm{R}, \mathrm{O}\}$ & 1 \\
\hline $\mathrm{Z}=\mathrm{O}_{2}$ & $\{\mathrm{~L}, \mathrm{Z}\}$ & $\{\mathrm{L}, \mathrm{Z}\}$ & $\{\mathrm{L}, \mathrm{Z}\}$ & $\{\mathrm{L}, \mathrm{Z}\}$ & 1 \\
\hline $\mathrm{ZY}=\mathrm{H}^{+}$ & $\{\mathrm{M}, \mathrm{N}, \mathrm{B}\}$ & $\{\mathrm{M}, \mathrm{N}, \mathrm{B}\}$ & $\{\mathrm{M}, \mathrm{N}, \mathrm{B}\}$ & $\{\mathrm{M}, \mathrm{N}, \mathrm{B}\}$ & 1 \\
\hline $\mathrm{XZ}=$ Electron Carriers & $\{\mathrm{R}, \mathrm{V}, \mathrm{K}\}$ & $\{\mathrm{R}, \mathrm{V}, \mathrm{K}\}$ & $\{\mathrm{R}, \mathrm{V}, \mathrm{K}\}$ & $\{\mathrm{R}, \mathrm{V}, \mathrm{K}\}$ & 1 \\
\hline
\end{tabular}

$\mathrm{C}(\mathrm{Ge}, \mathrm{Gs})=\frac{1}{|V|} \sum_{\mathrm{iv}} C i$, where $V=V e \cup V s$.Therefore the total closeness index, $=0.99$ 
TABLE 3: The closeness index mean score of High Achievers

High Achievers

1st group 2nd group $\quad 3^{\text {rd }}$ group

Total Closeness index scores

0.99

0.96

0.93

Mean scores

TABLE 4: Comparison between expert's (teacher's) node and nodes of First group of Middle Achievers concept map as sample for second and third groups

\begin{tabular}{|c|c|c|c|c|c|}
\hline $\mathbf{U}$ & $\mathbf{N}_{n}^{(\mathbf{E})}$ & $\mathbf{N}_{n}(\mathrm{~s})$ & $\mathbf{I}_{\mathbf{n}}$ & $\mathbf{U}_{\mathbf{n}}$ & $\mathbf{C}_{\mathbf{n}}$ \\
\hline $\mathrm{A}=$ Mitochondrion & $\{\mathrm{C}, \mathrm{D}, \mathrm{E}\}$ & $\{\mathrm{C}, \mathrm{D}, \mathrm{E}\}$ & $\{\mathrm{C}, \mathrm{D}, \mathrm{E}\}$ & $\{\mathrm{C}, \mathrm{D}, \mathrm{E}\}$ & 1 \\
\hline $\mathrm{B}=$ Outer Membrane & $\{\mathrm{D}, \mathrm{C}\}$ & $\{\mathrm{D}, \mathrm{C}\}$ & $\{\mathrm{D}, \mathrm{C}\}$ & $\{\mathrm{D}, \mathrm{C}\}$ & 1 \\
\hline $\mathrm{C}=$ Matrix & $\{\mathrm{C}, \mathrm{A}, \mathrm{D}\}$ & $\{\mathrm{C}, \mathrm{A}, \mathrm{D}\}$ & $\{\mathrm{C}, \mathrm{A}, \mathrm{D}\}$ & $\{\mathrm{C}, \mathrm{A}, \mathrm{D}\}$ & 1 \\
\hline $\mathrm{D}=$ Inner Membrane & $\{\mathrm{M}, \mathrm{T}, \mathrm{N}\}$ & $\{\mathrm{M}, \mathrm{T}, \mathrm{N}\}$ & $\{\mathrm{M}, \mathrm{T}, \mathrm{N}\}$ & $\{\mathrm{M}, \mathrm{T}, \mathrm{N}\}$ & 1 \\
\hline $\mathrm{E}=$ Membrane gaps & $\{\mathrm{D}, \mathrm{E}\}$, & $\{\mathrm{D}, \mathrm{E}\}$, & $\{\mathrm{D}, \mathrm{E}\}$, & $\{\mathrm{D}, \mathrm{E}\}$, & 1 \\
\hline $\mathrm{F}=$ Folds & $\{\mathrm{A}, \mathrm{C}\}$ & $\{\mathrm{A}, \mathrm{C}\}$ & $\{\mathrm{A}, \mathrm{C}\}$ & $\{\mathrm{A}, \mathrm{C}\}$ & 1 \\
\hline $\mathrm{G}=$ Energy Flow & $\{\mathrm{B}, \mathrm{Y}, \mathrm{Q}\}$ & $\{\mathrm{B}, \mathrm{Y}, \mathrm{Q}\}$ & $\{\mathrm{B}, \mathrm{Y}, \mathrm{Q}\}$ & $\{\mathrm{B}, \mathrm{Y}, \mathrm{Q}\}$ & 1 \\
\hline $\mathrm{H}=$ Cellular Respiration & $\{\mathrm{J}, \mathrm{A}, \mathrm{V}\}$ & $\{\mathrm{J}, \mathrm{A}, \mathrm{V}\}$ & $\{\mathrm{J}, \mathrm{A}, \mathrm{V}\}$ & $\{\mathrm{J}, \mathrm{A}, \mathrm{V}\}$ & 1 \\
\hline $\mathrm{I}=$ Internal Respiration & $\{\mathrm{V}, \mathrm{J}, \mathrm{A}\}$ & $\{\mathrm{V}, \mathrm{J}, \mathrm{A}\}$ & $\{\mathrm{V}, \mathrm{J}, \mathrm{A}\}$ & $\{\mathrm{V}, \mathrm{J}, \mathrm{A}\}$ & 1 \\
\hline $\mathrm{J}=$ Glycolysis & $\{\mathrm{L}, \mathrm{J}\}$ & $\{\mathrm{L}, \mathrm{J}\}$ & $\{\mathrm{L}, \mathrm{J}\}$ & $\{\mathrm{L}, \mathrm{J}\}$ & 1 \\
\hline $\mathrm{K}=$ Pyruvic Acid & $\{\mathrm{Q}, \mathrm{J}\}$, & $\{\mathrm{Q}, \mathrm{J}\}$, & $\{\mathrm{Q}, \mathrm{J}\}$, & $\{\mathrm{Q}, \mathrm{J}\}$, & 1 \\
\hline $\mathrm{L}=$ Glucose & $\{\mathrm{XY}, \mathrm{Z}\}$ & $\{\mathrm{XY}, \mathrm{Z}\}$ & $\{\mathrm{XY}, \mathrm{Z}\}$ & $\{\mathrm{XY}, \mathrm{Z}\}$ & 1 \\
\hline $\mathrm{M}=$ Cytoplasm & $\{\mathrm{N}, \mathrm{Y}, \mathrm{K}\}$ & $\langle\mathrm{N}, \mathrm{Y}, \mathrm{K}\}$ & $\{\mathrm{N}, \mathrm{Y}, \mathrm{K}\}$ & $\{\mathrm{N}, \mathrm{Y}, \mathrm{K}\}$ & 1 \\
\hline $\mathrm{N}=\mathrm{NADH}$ & $\{\mathrm{V}, \mathrm{O}\}$ & $\{\mathrm{V}, \mathrm{O}\}$ & $\{\mathrm{V}, \mathrm{O}\}$ & $\{\mathrm{V}, \mathrm{O}\}$ & 1 \\
\hline $\mathrm{O}=\mathrm{ATP}$ & $\{\mathrm{N}, \mathrm{K}\}$ & $\{\mathrm{N}, \mathrm{K}\}$ & $\{\mathrm{N}, \mathrm{K}\}$ & $\{\mathrm{N}, \mathrm{K}\}$ & 1 \\
\hline $\mathrm{P}=$ Krebs cycle & $\overline{\{N, X, Z\}}$ & $\{\mathrm{N}, \mathrm{X}, \mathrm{Z}\}$ & $\overline{\{N, X, Z\}}$ & $\overline{\{N, X, Z\}}$ & 1 \\
\hline $\mathrm{Q}=\mathrm{CO}_{2}$ & $\{\mathrm{~V}, \mathrm{~N}, \mathrm{~B}\}$ & $\left\{\mathrm{V}, \mathrm{M}^{*}, \mathrm{~B}\right\}$ & $\{\mathrm{V}, \mathrm{B}\}$ & $\left\{\mathrm{V}, \mathrm{N}, \mathrm{B}, \mathrm{M}^{*}\right\}$ & 0.8 \\
\hline $\mathrm{R}=$ Electron Transport & $\{\mathrm{U}, \mathrm{Z}\}$ & $\{\mathrm{U}, \mathrm{Z}\}$ & $\{\mathrm{U}, \mathrm{Z}\}$ & $\{\mathrm{U}, \mathrm{Z}\}$ & 1 \\
\hline $\mathrm{S}=\mathrm{ADP}$ & $\{\mathrm{O}, \mathrm{R}, \mathrm{Y}\}$ & $\{\mathrm{O}, \mathrm{R}, \mathrm{Y}\}$ & $\{\mathrm{O}, \mathrm{R}, \mathrm{Y}\}$ & $\{\mathrm{O}, \mathrm{R}, \mathrm{Y}\}$ & 1 \\
\hline $\mathrm{T}=$ Energy Investment Phase & $\{\mathrm{X}, \mathrm{R}, \mathrm{Y}\}$ & $\{\mathrm{X}, \mathrm{R}, \mathrm{Y}\}$ & $\{\mathrm{X}, \mathrm{R}, \mathrm{Y}\}$ & $\{\mathrm{X}, \mathrm{R}, \mathrm{Y}\}$ & 1 \\
\hline $\mathrm{U}=$ Energy Harvest Phase & $\{\mathrm{Q}, \mathrm{N}, \mathrm{O}\}$ & $\{\mathrm{Q}, \mathrm{N}, \mathrm{O}\}$ & $\{\mathrm{Q}, \mathrm{N}, \mathrm{O}\}$ & $\{\mathrm{Q}, \mathrm{N}, \mathrm{O}\}$ & 1 \\
\hline $\mathrm{V}=$ Acetyl CoA & $\{\mathrm{Q}, \mathrm{O}, \mathrm{X}, \mathrm{N}\}$ & $\{\mathrm{Q}, \mathrm{N}, \mathrm{X} ?\}$ & $\{\mathrm{Q}, \mathrm{N}, \mathrm{X} ?\}$ & $\{\mathrm{Q}, \mathrm{N}, \mathrm{X} ?\}$ & 0.8 \\
\hline $\mathrm{W}=\mathrm{FAD}$ & $\{\mathrm{R}, \mathrm{N}, \mathrm{K}\}$ & $\{\mathrm{R}, \mathrm{N}, \mathrm{M} *\}$ & $\{\mathrm{R}, \mathrm{N}\}$ & $\left\{\mathrm{R}, \mathrm{N}, \mathrm{K}, \mathrm{K}^{*}\right\}$ & 0.8 \\
\hline $\mathrm{X}=\mathrm{FADH}_{2}$ & $\{\mathrm{~A}, \mathrm{D}, \mathrm{C}\}$ & $\{\mathrm{A}, \mathrm{D}, \mathrm{C}\}$ & $\{\mathrm{A}, \mathrm{D}, \mathrm{C}\}$ & $\{\mathrm{A}, \mathrm{D}, \mathrm{C}\}$ & 1 \\
\hline $\mathrm{Y}=\mathrm{H}_{2} \mathrm{O}$ & $\{\mathrm{X}, \mathrm{R}, \mathrm{O}\}$ & $\{\mathrm{X}, \mathrm{R}, \mathrm{O}\}$ & $\{\mathrm{X}, \mathrm{R}, \mathrm{O}\}$ & $\{\mathrm{X}, \mathrm{R}, \mathrm{O}\}$ & 1 \\
\hline $\mathrm{Z}=\mathrm{O}_{2}$ & $\{\mathrm{~L}, \mathrm{Z}\}$ & $\{\mathrm{L}, \mathrm{Z}\}$ & $\{\mathrm{L}, \mathrm{Z}\}$ & $\{\mathrm{L}, \mathrm{Z}\}$ & 1 \\
\hline $\mathrm{XY}=\mathrm{H}^{+}$ & $\{\mathrm{M}, \mathrm{N}, \mathrm{B}\}$ & $\{\mathrm{M}, \mathrm{N}, \mathrm{B}\}$ & $\{\mathrm{M}, \mathrm{N}, \mathrm{B}\}$ & $\{\mathrm{M}, \mathrm{N}, \mathrm{B}\}$ & 1 \\
\hline $\mathrm{ZY}=$ Electron Carriers & $\{\mathrm{R}, \mathrm{V}, \mathrm{K}\}$ & $\{\mathrm{R}, \mathrm{V}, \mathrm{K}\}$ & $\{\mathrm{R}, \mathrm{V}, \mathrm{K}\}$ & $\{\mathrm{R}, \mathrm{V}, \mathrm{K}\}$ & 1 \\
\hline
\end{tabular}

$\mathrm{C}(\mathrm{Ge}, \mathrm{Gs})=\frac{1}{|V|} \sum_{\mathrm{iv}} C i$, where $\mathrm{V}=\mathrm{Ve} \cup \mathrm{Vs}$. Therefore the total closeness index, $=0.97$ 
Table 5: The closeness index mean score of Middle Achievers

Middle Achievers 1st group 2nd group 3rd group

$\begin{array}{lllll}\text { Total Closeness index } & 0.97 & 0.96 & 0.94 & 0.95\end{array}$

Mean

TABLE 6: Comparison between expert's (teacher's) node and nodes of First group of Lower Achievers concept map

\begin{tabular}{|c|c|c|c|c|c|}
\hline & $\mathrm{N}_{\mathrm{n}}^{(\mathrm{E})}$ & $\mathrm{N}_{\mathrm{n}}^{(\mathrm{s})}$ & $\mathrm{I}_{\mathrm{n}}$ & $\mathrm{U}_{\mathrm{n}}$ & $\mathrm{C}_{\mathrm{n}}$ \\
\hline $\mathrm{A}=$ Mitochondrion & $\{\mathrm{C}, \mathrm{D}, \mathrm{E}\}$ & $\{\mathrm{C}, \mathrm{D}, \mathrm{E}\}$ & $\{\mathrm{C}, \mathrm{D}, \mathrm{E}\}$ & $\{\mathrm{C}, \mathrm{D}, \mathrm{E}\}$ & 1 \\
\hline $\mathrm{B}=$ Outer Membrane & $\{\mathrm{D}, \mathrm{C}\}$ & $\{\mathrm{D}, \mathrm{C}\}$ & $\{\mathrm{D}, \mathrm{C}\}$ & $\{\mathrm{D}, \mathrm{C}\}$ & 1 \\
\hline $\mathrm{C}=$ Matrix & $\{\mathrm{C}, \mathrm{A}, \mathrm{D}\}$ & $\{\mathrm{C}, \mathrm{A}, \mathrm{D}\}$ & $\{\mathrm{C}, \mathrm{A}, \mathrm{D}\}$ & $\{\mathrm{C}, \mathrm{A}, \mathrm{D}\}$ & 1 \\
\hline $\mathrm{D}=$ Inner Membrane & $\{\mathrm{M}, \mathrm{T}, \mathrm{N}\}$ & $\{\mathrm{M}, \mathrm{T}, \mathrm{N}\}$ & $\{\mathrm{M}, \mathrm{T}, \mathrm{N}\}$ & $\{\mathrm{M}, \mathrm{T}, \mathrm{N}\}$ & 1 \\
\hline $\mathrm{E}=$ Membrane gaps & $\{\mathrm{D}, \mathrm{E}\}$, & $\{\mathrm{D}, ?\}$ & $\{\mathrm{D}, ?\}$ & $\{\mathrm{D}, \mathrm{E}\}$, & 0.6 \\
\hline $\mathrm{F}=$ Folds & $\{\mathrm{A}, \mathrm{C}\}$ & $\{\mathrm{A}, \mathrm{C}\}$ & $\{\mathrm{A}, \mathrm{C}\}$ & $\{\mathrm{A}, \mathrm{C}\}$ & 1 \\
\hline $\mathrm{G}=$ Energy Flow & $\{\mathrm{B}, \mathrm{Y}, \mathrm{Q}\}$ & $\{\mathrm{B}, \mathrm{Y}, \mathrm{Q}\}$ & $\{\mathrm{B}, \mathrm{Y}, \mathrm{Q}\}$ & $\{\mathrm{B}, \mathrm{Y}, \mathrm{Q}\}$ & 1 \\
\hline $\mathrm{H}=$ Cellular Respiration & $\{\mathrm{J}, \mathrm{A}, \mathrm{V}\}$ & $\{\mathrm{J}, \mathrm{A}, \mathrm{V}\}$ & $\{\mathrm{J}, \mathrm{A}, \mathrm{V}\}$ & $\{\mathrm{J}, \mathrm{A}, \mathrm{V}\}$ & 1 \\
\hline I = Internal Respiration & $\{\mathrm{V}, \mathrm{J}, \mathrm{A}\}$ & $\{\mathrm{V}, \mathrm{J}, \mathrm{A}\}$ & $\{\mathrm{V}, \mathrm{J}, \mathrm{A}\}$ & $\{\mathrm{V}, \mathrm{J}, \mathrm{A}\}$ & 1 \\
\hline $\mathrm{J}=$ Glycolysis & $\{\mathrm{L}, \mathrm{J}\}$ & $\{\mathrm{L}, \mathrm{J}, \mathrm{N} *\}$ & $\{\mathrm{L}, \mathrm{J}\}$ & $\left\{\mathrm{L}, \mathrm{J}, \mathrm{N}^{*}\right\}$ & 0.6 \\
\hline $\mathrm{K}=$ Pyruvic Acid & $\{\mathrm{Q}, \mathrm{J}\}$, & $\{\mathrm{Q}, \mathrm{J}\}$, & $\{\mathrm{Q}, \mathrm{J}\}$, & $\{\mathrm{Q}, \mathrm{J}\}$, & 1 \\
\hline $\mathrm{L}=$ Glucose & $\{\mathrm{XY}, \mathrm{Z}\}$ & $\{\mathrm{XY}, \mathrm{Z}\}$ & $\{\mathrm{XY}, \mathrm{Z}\}$ & $\{\mathrm{XY}, \mathrm{Z}\}$ & 1 \\
\hline $\mathrm{M}=$ Cytoplasm & $\{\mathrm{N}, \mathrm{Y}, \mathrm{K}\}$ & $\{\mathrm{N}, \mathrm{Y}, \mathrm{K}\}$ & $\{\mathrm{N}, \mathrm{Y}, \mathrm{K}\}$ & $\{\mathrm{N}, \mathrm{Y}, \mathrm{K}\}$ & 1 \\
\hline $\mathrm{N}=\mathrm{NADH}$ & $\{\mathrm{V}, \mathrm{O}\}$ & $\{\mathrm{V}, \mathrm{O}\}$ & $\{\mathrm{V}, \mathrm{O}\}$ & $\{\mathrm{V}, \mathrm{O}\}$ & 1 \\
\hline $\mathrm{O}=\mathrm{ATP}$ & $\{\mathrm{N}, \mathrm{K}\}$ & $\{\mathrm{N}, \mathrm{K}\}$ & $\{\mathrm{N}, \mathrm{K}\}$ & $\{\mathrm{N}, \mathrm{K}\}$ & 1 \\
\hline $\mathrm{P}=$ Krebs cycle & $\{\mathrm{N}, \mathrm{X}, \mathrm{Z}\}$ & $\langle\mathrm{N}, \mathrm{X}, \mathrm{Z}\}$ & $\{\mathrm{N}, \mathrm{X}, \mathrm{Z}\}$ & $\{\mathrm{N}, \mathrm{X}, \mathrm{Z}\}$ & 1 \\
\hline $\mathrm{Q}=\mathrm{CO}_{2}$ & $\{\mathrm{~V}, \mathrm{~N}, \mathrm{~B}\}$ & $\{\mathrm{V}, \mathrm{N}, \mathrm{B}\}$ & $\{\mathrm{V}, \mathrm{N}, \mathrm{B}\}$ & $\{\mathrm{V}, \mathrm{N}, \mathrm{B}\}$ & 1 \\
\hline $\mathrm{R}=$ Electron Transport & $\{\mathrm{U}, \mathrm{Z}\}$ & $\{\mathrm{U} ?\}$ & $\{\mathrm{U}, ?\}$ & $\left\{\mathrm{U}, \mathrm{Z}^{*}\right\}$ & 0.8 \\
\hline $\mathrm{S}=\mathrm{ADP}$ & $\{\mathrm{O}, \mathrm{R}, \mathrm{Y}\}$ & $\{\mathrm{O}, \mathrm{R}, \mathrm{Y}\}$ & $\{\mathrm{O}, \mathrm{R}, \mathrm{Y}\}$ & $\{\mathrm{O}, \mathrm{R}, \mathrm{Y}\}$ & 1 \\
\hline $\mathrm{T}=$ Energy Investment Phase & $\{\mathrm{X}, \mathrm{R}, \mathrm{Y}\}$ & $\{\mathrm{X}, \mathrm{R}, \mathrm{Y}\}$ & $\{\mathrm{X}, \mathrm{R}, \mathrm{Y}\}$ & $\{\mathrm{X}, \mathrm{R}, \mathrm{Y}\}$ & 1 \\
\hline $\mathrm{U}=$ Energy Harvest Phase & $\{\mathrm{Q}, \mathrm{N}, \mathrm{O}\}$ & $\{\mathrm{Q}, \mathrm{N}, \mathrm{O}\}$ & $\{\mathrm{Q}, \mathrm{N}, \mathrm{O}\}$ & $\{\mathrm{Q}, \mathrm{N}, \mathrm{O}\}$ & 1 \\
\hline $\mathrm{V}=$ Acetyl CoA & $\{\mathrm{Q}, \mathrm{O}, \mathrm{X}, \mathrm{N}\}$ & $\{\mathrm{Q}, \mathrm{O}, \mathrm{X}, \mathrm{N}\}$ & $\{\mathrm{Q}, \mathrm{O}, \mathrm{X}, \mathrm{N}$ & $\{\mathrm{Q}, \mathrm{O}, \mathrm{X}, \mathrm{N}\}$ & 1 \\
\hline $\mathrm{W}=\mathrm{FAD}$ & $\{\mathrm{R}, \mathrm{N}, \mathrm{K}\}$ & $\{\mathrm{R}, \mathrm{N}, \mathrm{K}\}$ & $\{\mathrm{R}, \mathrm{N}, \mathrm{K}\}$ & $\{\mathrm{R}, \mathrm{N}, \mathrm{K}\}$ & 1 \\
\hline $\mathrm{X}=\mathrm{FADH}_{2}$ & $\{\mathrm{~A}, \mathrm{D}, \mathrm{C}\}$ & $\{\mathrm{A}, \mathrm{D}, \mathrm{C}\}$ & $\{\mathrm{A}, \mathrm{D}, \mathrm{C}\}$ & $\{\mathrm{A}, \mathrm{D}, \mathrm{C}\}$ & 1 \\
\hline $\mathrm{Y}=\mathrm{H}_{2} \mathrm{O}$ & $\{\mathrm{X}, \mathrm{R}, \mathrm{O}\}$ & $\{\mathrm{X}, \mathrm{R}, \mathrm{O}\}$ & $\{\mathrm{X}, \mathrm{R}, \mathrm{O}\}$ & $\{\mathrm{X}, \mathrm{R}, \mathrm{O}\}$ & 1 \\
\hline $\mathrm{Z}=\mathrm{O}_{2}$ & $\{\mathrm{~L}, \mathrm{Z}\}$ & $\{\mathrm{L}, \mathrm{Z}\}$ & $\{\mathrm{L}, \mathrm{Z}\}$ & $\{\mathrm{L}, \mathrm{Z}\}$ & 1 \\
\hline $\mathrm{XY}=\mathrm{H}^{+}$ & $\{\mathrm{M}, \mathrm{N}, \mathrm{B}\}$ & $\{\mathrm{M}, \mathrm{N}, \mathrm{B}\}$ & $\{\mathrm{M}, \mathrm{N}, \mathrm{B}\}$ & $\{\mathrm{M}, \mathrm{N}, \mathrm{B}\}$ & 1 \\
\hline $\mathrm{ZY}=$ Electron Carriers & $\{\mathrm{R}, \mathrm{V}, \mathrm{K}\}$ & $\{\mathrm{R}, \mathrm{V}, \mathrm{O} *\}$ & $\{\mathrm{R}, \mathrm{K}\}$ & $\{\mathrm{R}, \mathrm{V}, \mathrm{K}, \mathrm{O} *\}$ & 0.8 \\
\hline
\end{tabular}

$\mathrm{C}(\mathrm{Ge}, \mathrm{Gs})=\frac{1}{|V|} \sum_{\mathrm{iv}} C i$, where $V=V e \cup V s$. Therefore the total closeness index, $=0.95$

TABLE 7: Closeness index mean scores of Low Achievers

Low Achievers $\quad 1^{\text {st }}$ group $2^{\text {nd }}$ group $3^{\text {rd }}$ group Mean Scores

$\begin{array}{lllll}\text { Total Closeness index scores } & 0.95 & 0.92 & 0.88 & 0.91\end{array}$

H3: There is significant difference between concept maps designed by students in the experimental group before and after the intervention techniques.

This hypothesis was tested using t-test statistical descriptive analysis of the pre- and postinterventional scores of the nine Achievement levels

in Table 8. The outcome of the t-test analysis is presented in Table 9. At the significance level of 0.05 , the calculated $t$-value was found to be greater than the tabulated $t$-value; therefore the third hypothesis can not be rejected. This means, there is a significant difference between students' score at the pre- and post-interventional stages. 
Table 8: Comparison of pre-test and post test scores of the experimental group

\begin{tabular}{|c|c|c|c|c|c|c|c|c|c|}
\hline \multirow[b]{2}{*}{ Achievers groups } & \multicolumn{3}{|c|}{ High } & \multicolumn{3}{|c|}{ Middle } & \multicolumn{3}{|c|}{ Low } \\
\hline & 1 & 2 & 3 & 4 & 5 & 6 & 7 & 8 & 9 \\
\hline Pre-test scores & 60 & 54 & 50 & 38 & 35 & 34 & 30 & 28 & 26 \\
\hline Post-test scores & 89 & 95 & 88 & 87 & 78 & 84 & 92 & 78 & 68 \\
\hline
\end{tabular}

TABLE 9: t-test analysis for pre-test and post-test scores

\begin{tabular}{lll}
\hline & Pre-test scores & Post-test scores \\
\hline Mean & 39.44444444 & 84.33333333 \\
Variance & 149.7777778 & 70.25 \\
Observations & 9 & 9 \\
t Stat & -14.5121084 & \\
t Critical one-tail & 1.859548038 &
\end{tabular}

\section{Discussion}

The results of the three hypotheses in Tables 3, 5 and 7 show significant increase in academic performance of SHS students in glycolysis and the Krebs cycle. The closeness index score of 0.99 obtained by the High Achievers shows a high conceptual understanding of the subject matter. The closeness index scores of 0.97 and 0.95 obtained by the Middle Achievers and the Low Achievers also express high gains of conceptual understanding of those groups compared to their peers (groups of the same achievement levels). Surprisingly, the scores of the post-interventional exercise in Table 8 shows either a higher performance score or very close scores among the Low Achievers compared to the scores of either the High or the Middle Achievers. For instance, the first group of the Low Achievers scored 92 which are higher than the score obtained by the second group in the First achievers' group. Computation of the average means scores of the post interventional exercise for the three main Achieving levels: High Achievers, Middle Achievers and Low Achievers were $90.7,83$ and 79 respectively. These outcomes prove that the skills and understanding of concept mapping acquired by individual students in the nine groups did not differ. This suggests that an individual ability to construct a good concept map is not limited to any ability group, therefore, students should be encouraged to improve upon their understanding of concepts using concept mapping (Ameyaw, 2012).

A concept map is an essential teaching strategy for teaching and learning of concepts perceived as difficult by students. Teachers should therefore adopt it as a teaching strategy and also encourage their students to make use of it in their studies.

\section{Conclusions}

The conclusion is line with Ameyaw (2012) that concept map encourages students to represent their vision of how a knowledge domain of a concept is structured and foster reflection of how nodes are interrelated. Concept map liberate students from academic challenges they face when learning concepts are perceived to be abstract in nature. It also gives students the freedom to visualize and present their own ideas in a more presentable manner. Finally, the closeness index calculation makes scoring easier without putting any restrictions on teachers during scoring.

\section{Acknowledgements}

I thank the Staff and Students of Odorgonno Senior High Schools in the Ga South Metropolis of the Greater Accra Region of Ghana for the support they gave to me during this research.

\section{References}

1) Abimbola, I. O. (1987). Cognitive science and its implications for science curriculum and instruction. Journal of Applied Research in Education, 1(1), 38-46.

2) Ameyaw, Y. (2012). Closeness Index (CI): An assessment tool for students' performance of Cell Theory. International Journal of Science and Nature, 3 (3)

3) Ausubel, D. (1978). Educational psychology: A cognitive view (Holt, Rinehart, \& Winston). http://dx.doi.org/10.3102/00028312006002287

4) Ausubel, D. P., Novak, J. D. \& Hanesian, H. (1978). Educational psychology: A Cognitive view (2nd ed.). New York: Holt, Rinehart and Winston. http://dx.doi.org/10.3102/00028312006002287

5) Beyerbach, B. \& Smith, J. (1990). Using a computerized concept mapping program to assess pre-service teachers' thinking about effective teaching. Journal of Research in Science Teaching, 27(10), 961-971. http://dx.doi.org/10.1002/tea.3660271005 
6) Cañas, J. A., Coffey, J. W., Carnot, J. M., Feltovich, P., Hoffman, R. R., Feltovich. J., \& Novak, D. J. (2003). A Summary of Literature Pertaining to the Use of Concept Mapping Techniques and Technologies for Education and Performance Support. The Institute for Human and Machine Cognition, Pensacola.

7) Chang, K. E., Sung, Y. T. \& Chen, S. F. (2001). Learning through computer-based Concept Mapping with scaffolding Aid. Journal of Computer Assisted Learning, 17(1), 21-33. http://dx.doi.org/10.1111/j.1365-2729.2001.00156.x

8) Creswell, J. W. (1994). RESEARCH DESIGN: Qualitative, Quantitative and Mixed Methods Approaches (2 ${ }^{\text {nd }}$ Ed.). SAGE Publications, Lincoln.

9) Edmondson, K. M. (1995). Concept mapping for the development of medical curricula. Journal of research in $\begin{array}{lll}\text { science } \quad \text { teaching, } & \text { 32(7), }\end{array}$ http://dx.doi.org/10.1002/tea.3660320709

10) Goldsmith, T. E., Johnson, P. J., \& Acton, W. H. (1991) Assessing structural knowledge. Journal of Educational Psychology, 83 (1), 88-96. http://dx.doi.org/10.1037//00220663.83.1.88

11) Horton, P. B., McConney, A. A., Gallo, M., Woods, A. L., Senn, G. J. \& Hamelin, D.(1993). An investigation of the effectiveness of concept mapping as an instructional tool. Science Education, 77(1), 95-111. http://dx.doi.org/10.1002/sce.3730770107

12) Keppel, G. (1991). Design and analysis of experiments. New Jersey:Prentice Hall. Chapter 3.
13) Marmaroti, P. \& Galanopoulou, D. (2006). "Pupils' understanding of photosynthesis: Aquestionnaire for the simultaneous assessment of all aspects." International Journal of Science Education 28 (4): 383-403. http://dx.doi.org/10.1080/09500690500277805

14) Mintzes, J. J., Wandersee, J. H. \& Novak, J. D. (2000). Assessing science understanding: A human constructivist view. San Diego: Academic Press. http://dx.doi.org/10.1111/j.1541-4329.2008.00057.x

15) Novak, J. D. (1998). Learning, creating, and using knowledge: Concept maps $(R)$ as facilitative tools in schools and corporations. Mahweh, NJ: Lawrence ErlbaumAssociates. http://dx.doi.org/10.4324/9781410601629

16) Novak, J. D. \& Gowin, D. B. (1984). Learning how to learn. New York: Cambridge University Press. http://dx.doi.org/10.1017/cbo9781139173469

17) Seymour, J, \& Longdon, B. (1991). Respiration-that's breathing isn't It? J. Biol. Educ. 23(3):177-184.

18) Schmid, R. F. \& Telaro, G. (1990). Concept Mapping as an Instructional Strategy for High http://dx.doi.org/10.1080/00220671.1990.10885996

19) School Biology. Journal of Educational Research, 84(2), 78 85. http://dx.doi.org/10.1080/00220671.1990.10885996

20) Songer, C. J. \& Mintzes, J. J. (Aug, 1994). Understanding cellular respiration: An analysis of conceptual change in college biology._Journal of Research in Science Teaching. Volume 31, Issue 6, pages 621-637. Wiley Periodicals, Inc. http://dx.doi.org/10.1002/tea.3660310605 